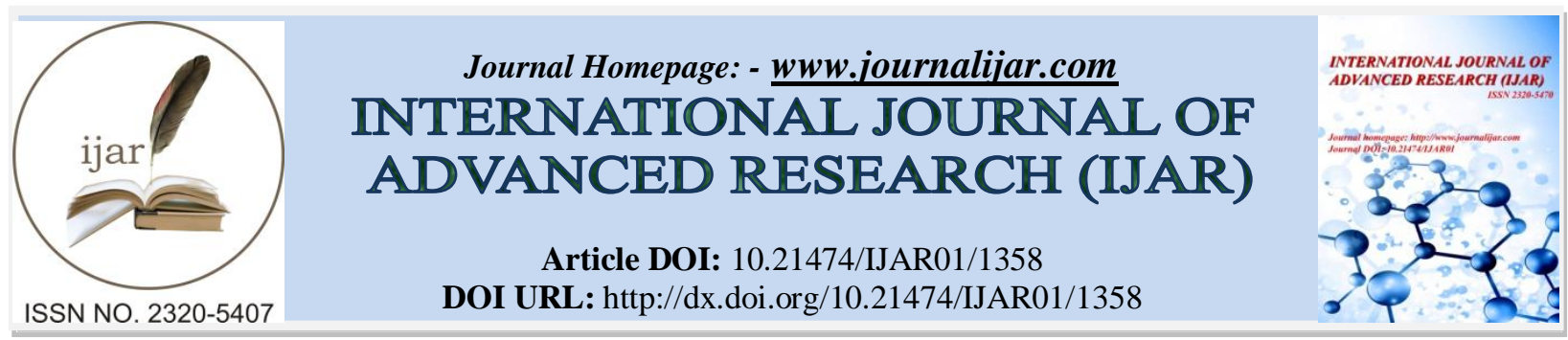

RESEARCH ARTICLE

\title{
A COMPARATIVE STUDY ON FINANCIAL REPORTING PRACTICES IN INDIA, US AND UK IN LINE WITH IFRS.
}

Sidhartha Sharma.

Assistant Professor in CBM Department, D.A.V University Jalandhar city, Punjab.

\section{Manuscript Info}

Manuscript History

Received: 18 June 2016

Final Accepted: 19 July 2016

Published: August 2016

Key words:-

Accounting, International financial

reporting practices, international

dimensions of accounting, IFRS,

Accounting treatments.

\section{Abstract}

The story of the inception of business and commerce helps to provide a historical account of the evolution of accounting. The concept of accounting has gone from different transformational stages at domestic as well as international level. Complex interaction of various environmental variables like rapid expansion of international business, pre-dominance of MNC's, internationalization of capital markets and establishment of autonomous accounting bodies and institutions has lead to diversity and development of accounting rules, regulations, policies, procedures and framework at international level. Many recognized and esteemed accounting institutions at international level already have realized the complexities and diversity in context to international financial reporting practices in different countries. They have accepted the fact that different countries that are rich in accounting policies and practices are indifferent to the international dimensions of accounting and financial reporting practices in light with IFRS due to the complex interaction of different environmental variables like economic factors, political factors, socio-cultural factors and technological factors etc. In globalization era, the concept of international financial reporting practices is a well established era of specialization. The present paper laid emphasis on factors affecting international financial reporting practices in selected nations like India, U.S and U.K which are advance and rich in accounting system as well as it concentrate upon measuring the differences between the their preparation and presentation of financial statements. In other words, the present paper will also study the fact that how local GAAP of selected countries differs from IFRS on executing, recognition, measurement, and disclosure rules with regard to various accounting items like inventory valuation, revaluation of fixed assets, treatment of pre-operating expenses, amortization of intangible assets, consolidated statements, cash flow statements and foreign currency translations etc. 


\section{Introduction:-}

International financial reporting in common parlance refers to a broader concept which include the development of numerous factors like whom to disclose, what to disclose, when much to disclose and finally how to disclose at international level (Choi and Levich 1991). International financial reporting is commonly perceived not only to disclose financial information at world large but development of many factors which shapes and reshapes accounting rules, regulations, procedures and practices at international level ( Shima 2012). The main emphasis of international financial reporting lies on the establishment of effective accounting standards to enhance reliability, relevancy, consistency and creditability and moreover universality of accounting information at global level (Choi and Meek, 2008). The basic premise of international financial reporting practices at world large is depends on the following elements:-

- International financial reporting laid emphasis on fulfilling the specific need and nature of diverse accounting groups or user of accounting information at international level.

- International financial reporting lies on sound conceptual framework which plays a very important role in establishing a better position for accounting users and standard setter to access alternative accounting formats, methods and procedures.

- International financial reporting gives clues as well as solutions to problems like personal biasness and element of subjectivity which is prevailing in different countries in context to accounting practices.

- International financial reporting facilitates universality and harmonization of accounting practices at international level

\section{Review of Literature:-}

FREDERICK D.S CHOI (1991) concluded that investors and participants in the international capital market perceive accounting diversity as a major problem that affects the capital market decisions. The paper concluded the two main factors Firstly; differences in the accounting practices may affect the security valuation and the composition of international portfolios. Secondly, this paper described as effective ways of tiding over accounting diversity and its impact on international capital markets.

PETER JOOD \& MARK LANG (1994) explored the diversity in the accounting practices and policies of France, Germany and United Kingdom. This paper concluded the various factors. Firstly, the paper has explored the significant differences between ratio analysis and financial market valuation in their financial reporting practices. Secondly, it also provides preliminary evidence on the effects of the (EU) European Union directives on accounting measurement differences as well as differences in reporting practices.

SUSANA \& JOSE A LAINEZ (2000) found that existence of diversity in accounting principles and accounting system has significant consequences for the interpretation of financial reporting in global arena and, therefore, for the decisions which may be taken on the basis of the interpretation drawn from an analysis of such accounting information. The paper concluded the two main factors .Firstly, accounting diversity can be considered as a prime obstacle for the international comparability of financial reporting. Secondly, the paper have found the important differences in the situation of companies i.e. liquidity, solvency and profitability etc under different accounting principles.

HASSAN R. HASSABELNABY, RUTH W. EPPS AND AMAL A. SAID (2003) found that the impact of environmental variables on the development of accounting policies and reporting practices. Under their observation there were four dominating environmental variables which are used to explain the variation observed over time in accounting diversity and development in context to policies and reporting practices. These factors were the economic environment, the political environment, the development of the stock market, and privatization of state owned corporations. The paper concluded the two main factors. Firstly, the impact of the environmental variables on accounting development changes over time reflecting the different stages of democracy and economic reform. Secondly, it provides international investors and researchers with an in depth understanding of the dominating environmental variables that affect accounting practices in global arena.

LOANA MARIA DRAGU (2010) found that the global accounting conceptual framework, standards and reporting still continue to represent a mission for supreme international accounting bodies like (IASB) international accounting standard board and (FASB) financial accounting standard board, being far from the stage of practical implementation. Both accounting bodies are witnessing the diversity and complexities in reaction to accounting 
system in global arena. Thus, harmonizing both national and international accounting regulations is necessary so that it would be in accordance with companies' interest.

ADELA DEACONU \& ANUTA BUIGA (2011) witnessed the diversity between accounting systems of Continental-European type and Anglo-Saxon type respectively. The paper concluded many factors. Firstly, the paper examines the relevance of the criterion in the historic context and its impact on accounting policies and procedures. Secondly, it also studies the whole framework comprising economical, social, legal and political variables and their impact on financial reporting.

JOEL BRANSON \& MUIZ JAMIL (2011) observed that the main factors for diversity in accounting practices, policies and procedures and to better understand how accounting differences have a huge impact on accounting harmonization.The paper concluded the two main factors. Firstly, it strengthens the awareness of the existence of the causes for accounting diversity at international level. It is important to understand the current complexities and difficulties of the drive towards international accounting harmonization. Secondly, it also highlighted the in-depth analysis of the environmental variables that are considered most influential in causing accounting diversity.

\section{Research methodology:-}

Research methodology is a systematic process of solving the specific problem systematically by research. In other words, it is a general strategy that outlines the mechanism in which researcher is to be understood and many other things as well as to identify the method to be used in it.

\section{Research Objectives:-}

The present paper is concerned with fulfilling the following objectives:-

1. To study the key factors affecting international financial reporting practices.

2. To study Financial Reporting Practices in India, US and UK In Line With IFRS

\section{Need of The Study:-}

To aware the students, academicians as well as industrialist about how Indian GAAP differs from IFRS as well as selected countries like US and UK on executing, recognition, measurement, and disclosure rules with regard to various accounting items .

\section{Sources of Data:-}

The data used in the study is primary as well as secondary. Primary data has been collected on the basis of personal interactions with experts, academicians and the learned persons. On the contrary, secondary data is collected by reviewing various authentic research papers from online databases of peer reviewed journals, official websites of international accounting bodies and standards, quality books, professional magazines and newspapers.

\section{Sample Details:-}

The present study will be conducted for variations in IFRS adoption and financial reporting practices of selected countries. The sample size of 3 countries i.e. India, US and UK are taken to compare the difference in IFRS adoption and financial reporting practice. The basic premise of selecting respective countries with India is based on two main factors. Firstly, US (15.3\% of total India exports) and UK (3.4\% of total India exports) are the top trading partners of India during 2015 (Workman 2016). Therefore, comparative analysis of variations and differences in the financial reporting practices of the selected countries will help the students, academicians and experts to understand the concept as well as complexities of international financial reporting practices in many ways. Secondly, status of accounting profession is quite high in the selected countries. In other words, accounting principles and practices in India, US and UK has generally been held in high esteem. In such countries, accounting profession and accounting standards are self regulating and sufficient to meet the need of their industry.

\section{Factors affecting international financial reporting practices:-}

Accounting policies and practices prevailing in the nation are influenced by various environmental variables, but at the same time, it is one of the factors affecting on this same environment ( Adhikari \& Tondkar 1992). This is a fact that points to the interdependency of accounting and its environment. In other words, A nation's accounting policies , practices and procedures is affected by complex interaction of economic, socio - cultural, political, legal and many other environmental factors, so it is next to impossible to say that environmental factors of two or more 
countries are going to be similar (Nobes 1998). Nation's accounting principles and practices are the product of complex interaction of above environmental factors. It is unlikely that mix is identical in any two countries or more and therefore diversity is to be expected at global level (Choi and Meek, 2008). Some of the glorying factors which influence international financial reporting practices at world level are as follows:

\section{Accounting and Economic Environment:-}

The level of economic development of the country is likely to influence the type of business entities or groups exist in a country ( Beke, 2010). Developed countries like US and UK are more featured by large and complex organizations in comparison to developing countries like India, Pakistan and Sri Lanka. Financial recording and reporting practices will be more sound and complex in developed countries due to the presence of hefty number of multinational corporations.

\section{Accounting and Political Environment:-}

The political environment and system prevailing in a particular country will have a greater impact on the accounting policies, procedures and reporting. The way a country is politically governed can have considerable influence on accounting system. The relevance of political system can also see in many countries that are effectively run by dictators (Gernon and Meek, 2001). Countries like France and Netherlands still follow accounting system given by their colonial rulers. Likewise countries like India, NZ, Australia and Hong Kong has adopted the accounting system of Britishers.

\section{Accounting and Socio-Cultural Environment:-}

A major source of influence on accounting practices and procedures is socio-culture factor. Factors like secrecy v/s transparency, optimism v/s pessimism and uniformity v/s flexibility etc have a huge impact on the measurement of financial items as well as financial disclosure practices at world large (Jaggi 1975). Developed countries like US and UK are more transparent, optimistic and flexible than Japan, Germany, India and China etc when it comes to disclosure of financial records due to socio-cultural factors.

\section{Accounting and Legal Environment:-}

Legal environment is one of the most dominating factors for diversity in accounting practices in global arena. Different countries have their own legal structure and systems. Some countries are nationalistic and other is rationalistic. In other words, some countries possess strict legal system and other countries possess adaptive legal system (Daske \& Hail, 2008). Countries like France and Germany follows code law which is more legalistic, detailed, prescriptive, procedural and nationalistic. On the contrary, countries like US, UK and NZ and Australia follows common law which is more flexible, adaptive and innovative in comparison to code law.

\section{Accounting and Internationalization of Capital Market:-}

The elements of capital market have an impact on accounting practices and procedures. Difference in financial system, emergence of new and innovative financial securities and impact of GAAR etc factors leads to diversity in accounting practices, procedures and disclosure requirements (Guan and Lau, 2004). In debt oriented countries like Germany, Japan and Switzerland, financial reporting tends to be more Spartan against equity oriented countries like US, UK and Canada. The level of globalization of capital market or listing of securities at international level impacts financial recording and reporting practices to huge extent.

\section{Accounting and Emergence of Multinational Corporations:-}

Developed countries tend to have capitalistic economy as well as possess large and complex organizations, where accounting problems are far more complex and detrimental than those of small organizations in developing and underdeveloped countries (Radebaugh , 2006). In countries like US and UK, organizations are relatively large, complex and owned by large number of employees against developing countries like India, Pakistan and Sri Lanka. The extent of accounting principles and practices is likely to be maximum and complex in developed countries. 


\section{Accounting and Inflation:-}

An economy's level of inflation can also be perceived as an influencing factor in the context of diversity in accounting practices, policies and procedures, because it has a direct impact on the asset valuation method. It is advisable to opt for appropriate accounting system which supports the inflationary conditions of a particular country when inflation rate is prevailing quite high (Choi and Meek, 2008). Countries like US and UK are familiar with historical cost model when it comes to their accounting practices. On the contrary, countries like Bolivia and Mexico do not have luxury of persisting with the practice of historical cost model. They use inflation adjusted models of financial reporting to provide more decision relevant information in context to their economies.

\section{Accounting and Professional Bodies:-}

Number of accounting professional bodies has a direct link with the quality of accounting practices, policies and procedures that prevails in a particular country. The designing and standard of accounting system in a country is primarily depends upon the quality of professional bodies (Choi and Meek, 2008). Independent accounting professional bodies like (AASB) Australian accounting standard board, (AARF) Australian accounting research foundation, (ICAA) Institute of chartered accountants in Australia etc has a huge impact on Australian accounting principles, practices and disclosure practices. At global level, (IASB) international accounting standard board of United Kingdom and financial accounting standard board of USA are providing conceptual framework to satisfy the needs and nature of diverse groups of accounting users at global level which facilitate the harmonization and universality of information at global level.

\section{Accounting and Conceptual Framework:-}

Conceptual framework provides a logical and consistent guide to accounting standards that prevails in a particular country. While a conceptual framework does not have a compulsory status in every country, still it provides a reference point for developing and adopting accounting standards (Ali and Hwang, 2000). Countries like US, UK, Canada and Australia etc have invented their own version of conceptual framework in accordance with their own environmental variables. On the contrary, developing countries like India, Pakistan and Sri Lanka have a habit to follow conceptual framework of other countries.

\section{Accounting and Report Regime:-}

Type of report regime can also have a huge impact on the system of accounting as well as the financial reporting that prevails in a particular country (Choi and Meek, 2008). Countries like Austria and Germany who follow single set of rules i.e. same rules for financial as well as tax reporting looks rich in their report regime to potential investors but poor to tax authorities against countries like US, UK and India who use to follow double set of rules while reporting .

\section{Accounting and Cross Border Terrorism:-}

Cross border terrorism is not a new phenomenon particularly for Asian countries. However terrorist attack on 11 September, 2001 in US has made cross border terrorism an international issue. Developed country like US in particular is not only providing financial assistance to developing and under developed countries to fight against terrorism but also business and their own accounting system to carry out transactions in an efficient manner (CCAB report 2015)

\section{Comparative financial reporting practices in selected countries:-}

Comparative financial reporting practices in different countries implies the comparative as well as comprehensive reporting in consideration to different and complex accounting set of rules, regulations, procedures, principles and practices in different countries ( Mueller 1967). The basic premise of comparative financial reporting is to sort out the major differences as well as solutions to overcome such differences in order to provide universality in accounting at global level (H. Daske 2008). The scale of international financial reporting remains large, complex and diversified despite the adoption of international financial reporting standards (IFRS). In the light of the above problem, comparative analysis of financial reporting practices in India, US and UK in line with IFRS as well as which are rich in accounting profession and standards can be a handy tool to compare the differences in context to accounting aspects which arises due to the differences in environmental variables as well as to work out hard for similarity and harmonization of accounting recording and reporting practices. Some of the key accounting items and its preparation and presentation in selected countries are given below:- 


\section{Inventory Valuation:- \\ IFRS:-}

Under IFRS, IAS-2 'inventories' deals with the concept of inventories. In other words, the main source of accounting treatment of inventories is specifically mentioned under IAS-2. The value of inventory is measured on the basis of cost or net realizable value, whichever is less but in certain specific industry like financial industry, the value of inventory is determined on the basis of fair market value. Under IFRS, the most appropriate method for cost of inventory is FIFO and weighted average cost method. LIFO method which is one of the popular methods and used by many countries is strongly prohibited under IFRS. Specific identification inventory valuation method is allowed in case of specific projects.

\section{Indian GAAP:-}

Under Indian GAAP, AS-2 'valuation of inventories' deals with measurement as well as valuation of inventories. The valuation of inventory is measured on the basis of cost or net realizable value, whichever is less. Some of the popular methods of inventory valuation under Indian GAAP are FIFO, Weighted average, retail cost and standard cost method but overall Indian standards are consistent with IFRS when it comes to valuation and methods of inventory.

\section{US GAAP:-}

Under US GAAP, FASB accounting standard codification 330-10 deals with the meaning, measurement and methods of inventory valuation. This standard codification follows IAS-2 when it comes to measurement of inventory valuation i.e. cost or net realizable value, whichever is less but in case of methods of inventory valuation there is slight difference in the approach of US GAAP against IFRS. LIFO method is permitted for inventory valuation but the same was strongly prohibited under IFRS.

\section{UK GAAP:-}

SSAP-9 'inventories and long term contracts' deals with inventory accounting and valuation of inventories. UK GAAP is in line with IFRS with regard to inventory valuation i.e. cost or net realizable value, whichever is less but when it comes to method of inventory valuation, FIFO and weighted average inventory methods are the suitable methods for inventory valuation.

\section{Pre-Operating Expenses:- \\ IFRS:-}

Under IFRS, paragraph 69 of IAS 38 deals with the accounting treatment of pre-operating expenses. IAS 38 state that pre operating expenses like cost of plant, property and equipment, legal and secretarial cost, launching a new product or process etc are no more treated as deferred cost and shall be amortized over a number of period.

\section{Indian GAAP:-}

Under Indian GAAP, paragraph 56 of AS-26 \& guidance note 34- treatment of expenses during construction period deals with startup cost and pre operating expenses. It states that any direct revenue expenses which are incurred during the construction period are allowed to be capitalized and vice versa in case of indirect revenue expenses.

\section{US GAAP:-}

SFAS-7 deals with the concept of pre operating expenses. Surprisingly, the concept of pre operating expenses itself doesn't exist. In other words, SOP 985 under US GAAP provides clear cut guidelines regarding the treatment of respective expenses. Firstly, the business enterprise shall prepare income statement and balance sheet as it were a normal running organization and secondly, such expenses have to be charged to revenue and assets are capitalized as a normal organization.

\section{UK GAAP:-}

Under UK GAAP, paragraph 14 of FRS-15 deals with the accounting treatment of pre operating cost. Under UK GAAP, the accounting treatment of pre operating expenses are made on the basis of nature of activity. In other words, the pre operating expenses shall be treated in the same manner as similar cost incurred as a part of entity's ongoing activity. On the contrary, if the pre operating cost is not the part of business ongoing activity then the 
expenses related with pre operating expenses shall be included in the cost of tangible fixed assets if certain criterion is met.

\section{Revaluation of Fixed Assets:- IFRS:-}

Under IFRS, IAS-16 'plant, property and equipments' deals with revaluation of fixed assets. Under IFRS, cost model and revaluation model are utilized for the revaluation of fixed assets. Under cost model, the fixed assets are carried at their historical cost after deducting depreciation and accumulated impairment loss as the case may be and under revaluation model, the fixed asset is initially valued at cost but subsequently its carrying amount is increased on account of appreciation in value.

\section{Indian GAAP:-}

Under Indian GAAP, AS-10 'accounting for fixed assets' deals with the revaluation of fixed assets. Competent value method, indexation method and current market price method are three main methods for revaluation of fixed assets which are comprehensively defined under paragraph 13 of accounting standard 10. According to Indian GAAP, fixed asset should not be revalued selectively i.e. revaluation of fixed assets should be done for the entire class of fixed assets.

\section{US GAAP:-}

US GAAP FASB codification topic 360 'property, plant \& equipment' which provides guidelines in respect to revaluation of fixed assets. According to US GAAP, all fixed assets are accounted for using historical cost model, which stipulates that noncurrent assets are initially recognized at cost value as well as they are subsequently carried at cost less accumulated depreciation and cumulative impairment loss. It also state that revaluation of fixed asset can be done at fair market value if there is a case of business combinations.

\section{UK GAAP:-}

Under UK GAAP, FRS-15 'Tangible fixed assets' deals with the revaluation of fixed assets. FRS 15 state that tangible assets are accounted for on a consistent basis and that where there is a policy of revaluation of fixed assets, there revaluation are kept up to date. Tangible fixed assets should be measured initially at cost which is attributed to bringing the asset into productive or working situation. Subsequent expenditure should be capitalized where it increase overall economic benefits of the asset in excess of its previously assessed standard of performance or where it replaces or restores a component of the asset that has been treated separately for depreciation purpose.

\section{Depreciation of Fixed Assets:-}

IFRS:-

Under IFRS, IAS-16 'property, plant and equipment' deals with the alternative approach to accounting for fixed assets as well as depreciation on fixed Assets. Under IFRS, depreciation on fixed assets is based on the useful economic life of the assets. The method of depreciation should reflect the pattern in which the future economic benefits of the asset are likely to be consumed by the entity. Under IAS-16, straight line method, diminishing balance method and units of production methods are the most suitable as well as accepted methods of depreciation of fixed assets.

\section{Indian GAAP:-}

AS-6 'depreciation accounting' deals with the depreciation of fixed asset. It state that depreciation is always charged on tangible assets whereas intangible assets are subjected to amortization under AS-26. Under Indian GAAP, every tangible asset is subjected to depreciation from the date it is ready to use. Straight line method and reducing balance method are the most suitable method for charging depreciation on tangible fixed assets. Indian GAAP also guide that once the method is adopted must be followed on consistent basis and change of method is possible only if the adoption of the new depreciation method is required under statute or compliance with an accounting standard or if it is considered that such modification or change in the depreciation method would result in better financial reporting and presentation. 


\section{US GAAP:-}

US GAAP FASB codification topic 360 'property, plant \& equipment' deals with the depreciation of fixed assets. The provisions and methods of depreciation under US GAAP are in line with IFRS i.e. depreciation on fixed assets is based on the useful economic life of the assets. The method of depreciation should reflect the pattern in which the asset's future economic benefits are expected to be consumed by the entity. Straight line method, declining balance method and sum of the year's digit method are the suitable depreciation methods under US GAAP.

\section{UK GAAP:-}

Under UK GAAP, FRS-15 'Tangible fixed assets' deals with the depreciation of fixed assets. It state that depreciation on fixed asset is accounted on the basis of economic benefit consumed over the useful life of the concerned asset. Straight line method and reducing balance method are the suggested method of depreciation under UK GAAP. The depreciation amount of tangible fixed assets should be recognized in profit and loss account in a systematic manner as well as it reflects as fairly as possible the pattern in which the assets economic benefits are consumed by the entity over its useful economic life.

\section{Amortization of Intangible Assets:- \\ IFRS:-}

Under IFRS, paragraph 97 of IAS-38 deals with the amortization of intangible assets. In case of intangible assets with definite life, the depreciable amount should be amortized on a systematic basis over that life. The amortization method of intangible assets should demonstrate the pattern of consumption of the economic benefits expected from the asset. Generally, it is recorded in income statement unless it is permitted or required to be included in the carrying amount of another asset. Straight line method, diminishing balancing method and unit of production method are the amortization methods which can be used to allocate the amortized amount of intangible asset over the useful life of the same.

\section{INDIAN GAAP:-}

AS-26 ' intangible assets' deals with the amortization of intangible assets. According to Indian GAAP, the intangible assets are amortized in ratio of future economic benefits. This standard further state that the time period of amortization can be any number of years but it should be finite and generally it shall not exceed 10 years. Straight line method is one of the most preferable method of amortization of intangible assets.

\section{US GAAP:-}

US GAAP FASB codification topic 350-30 'intangible, goodwill and others' deals with the amortization of fixed assets. Under US GAAP, the cost of intangible assets are either amortized over their respective useful life or are tested for impairment on an annual basis. According to US GAAP, recognized intangible assets with definite useful life are amortized. Straight line amortization is the suitable method of amortization under US GAAP.

\section{UK GAAP:-}

FRS-10 ' accounting treatment of goodwill and intangible assets' deals with the amortization of intangible assets. Intangible assets having a limited useful economic life are required to be amortized over their useful economic life and the standard suggest that a rebuttable presumption that the useful economic life of the intangible assets which are confined to a maximum period of 20 years. Straight line method and reducing depreciation method are the methods which are suggested under UK GAAP for the amortization of intangible assets.

\section{Consolidation Of Financial Statements:- IFRS:-}

Under IFRS, IAS-27 deals with the preparation and presentation of consolidated financial statements or financial statements of group of entities under the control of a parent company. Under IFRS, it is mandatory for the parent company to prepare as well as present consolidated financial statements for reporting purpose. The basis for consolidation of financial statements is well defined by SIC-12 which set out the indicator of control i.e. when parent company acquires more than half of the voting rights of the entity and if not so then control may be evidence by power. Under IFRS, combine all accounting items like assets, liabilities, equity, income and expenses etc of the parent company with those of its subsidiaries either domestic or foreign both are taken into consideration. 


\section{Indian GAAP:-}

Under Indian GAAP, AS-21 set out the framework for consolidation of financial statements of group of enterprises under the control of the parent company. The basis of consolidation is the indicator of control i.e. the ownership, directly through subsidiary or indirectly through subsidiary, of more than one- half of the voting power of an enterprise: or Control of the proportion or composition of the corresponding governing body in case of any other enterprise so as to obtain economic benefits from its activates. According to the AS-21, a parent company should present consolidated financial statements of both domestic as well as foreign subsidiaries. It state that consolidated financial statements should be prepared and presented in addition to its main financial statements for better comparison and understanding.

\section{US GAAP:-}

Under US GAAP, financial accounting standard statement (SFAS) no. 94 deals with the consolidated financial statements. US GAAP is in line with IFRS when it comes to consolidation of financial statements i.e. combine all accounting items like assets, liabilities, equity, income and expenses etc of the parent company with those of its subsidiaries either domestic or foreign if parent company holds ownership of over $50 \%$ voting shares .

\section{UK GAAP;-}

FRS-2 which deals with 'accounting of subsidiary undertaking' state the required conditions under which an undertaking which is parent undertaking of other undertakings should prepare consolidated financial statements. They also set out the manner or mechanism in which consolidation of financial statements takes place and there are certain exceptions when consolidation is not mandatory for parent company if certain criteria is met .

\section{Cash Flows Statements:- IFRS:-}

IAS-7 deals with the accounting treatment and presentation of cash flow statements. Paragraph 45 of the accounting standard state that every business enterprise require to report movement of cash \& cash equivalents arising from three main activities i.e. operating, investing and financing activities. Under IFRS, every company whether listed or unlisted must include a cash flow statement as part of their main financial statements. It is noteworthy to state that the there is no sequence which is prescribed by the IFRS while preparing cash flow statements but it must be prepared for effective reporting and understanding.

\section{Indian GAAP:-}

AS-3 deals with the preparation and presentation of cash flow statements in India by Indian companies. The framework provided by the respective standard is quite similar or equivalent to IFRS or IAS-7 i.e. every company whether listed or unlisted must prepare and present a cash flow statement as part of their main financial statements as well as categorize it under three main categories i.e. operating, investing and financing activities.

\section{S GAAP:-}

US GAAP FASB codification topic 230-10-20 is the prime source of guidance for preparation and presentation of cash flow statements. Just like IFRS, cash flow statement is classified under three main activities i.e. operating, investing and financing activities. It state that, an entity is required to reconcile the amount of cash \& cash equivalents in its statement of cash flows with the equivalent to items reported in the statement of financial position.

\section{UK GAAP:-}

FRS-102 deals with the preparation and presentation of cash flow statements under UK GAAP. Under UK GAAP, there are nine main headings which are shown to see the movement of cash under cash flow statement like cash movement from operating activities, dividend from joint venture, return on investment, servicing of finance, taxation, capital expenditure, financial instruments, management of liquid resources and financing etc. every company is required to prepare a cash flow statement including increase and decrease of cash and cash equivalents from the above sources under UK GAAP. 


\section{Foreign Currency Translation:-}

IAS-21 deals with 'the effect of changes in foreign exchange rates' i.e. exchange rates, which exchange rate should be used and it impact and set outs how to account for transactions in foreign currencies and foreign operations. Under IFRS, foreign currency transactions should initially be recorded at the spot rate at the date of transaction. It requires the use of monetary method for foreign currency translations i.e. At each balance sheet date the monetary items should be recorded and reported at closing rates and non monetary items are carried at fair value. Exchange rate differences on monetary items are reported in profit and loss $\mathrm{a} / \mathrm{c}$ and exchange rate differences of non monetary items are recognized in equity.

\section{Indian GAAP:-}

Under Indian GAAP, AS-21 'effect of changes in foreign exchange rates' deals with foreign currency translations. The treatment of foreign currency translation is in line with IFRS i.e. monetary items should be recorded and reported at closing rates and non monetary items are carried at fair value.

\section{US GAAP:-}

US GAAP FASB codification topic 52 is the prime source of guidance for foreign currency translations. It requires the use of temporal method for foreign currency translations i.e. a key feature of this approach is the current rate approach, which translates all assets and liabilities at the current rate, equity accounts at historical rates and income statements at a weighted average rate for the period.

\section{UK GAAP:-}

FRS-23 'the effect of changes in foreign exchange rates' deals with the understanding and treatment of foreign currency. It requires the use of monetary/non-monetary method for foreign currency translations i.e. monetary items are generally translated in the functional currency at the exchange rate applicable at the end of the reporting period and non monetary items are measured at fair value translated at the rate of date when fair value is premeasured. Differences of exchange on monetary items are recognized in profit and loss a/c and exchange rate differences on non-monetary items are measured at fair value as well as recognized as part of change in fair value posted.

\section{Conclusion \& suggestions:-}

Accounting principles and practices are the product of environment. Different countries like India, US and UK are indifferent to international dimensions of accounting and financial reporting practices due to complex interaction of their own environmental variables like changed character of international capital market, predominance of MNC's , new accounting bodies, emergence of e-business, economic, legal, political, social and various other environmental variables has created the element of subjectivity. Therefore, It is next to impossible to bring perfection or harmonization to full extent in accounting system, policies and reporting practices in the selected countries as well as their adoption with IFRS due to different environmental factors prevailing in their own country but accounting differences at global level can be reduced by establishing effective accounting standards, formats, methods and procedures which are acceptable at global level. It is the duty of international accounting bodies and institutions like IASB and FASB establish such a global accounting conceptual framework by understanding the variations in international financial reporting practices which shall reduce the element of subjectivity and facilitate harmonization and universality of accounting at global level but still the universal accepted accounting conceptual framework continue to represent a mission for international accounting bodies.

\section{References:-}

1. A Adhikari, R. T. (1992). Environmental Factors Influencing Accounting Disclosure Requirements of Global Stock Exchanges. Journal of International Financial Management and Accounting, Volume 4(2): 75-105.

2. A. Ali, L. (2000). Country-Specific Factors Related to Financial Reporting and the Value Relevance of Accounting Data. Journal of Accounting Research, Spring(1): 1-21.

3. B, J. (1975). The impact of cultural enviornment on financial disclosures. international journal of accounting education and research , 75-84.

4. Beke, J. (2010). Business and economic aspects of accounting standardisation. Business and economic horizons , Volume 2, Pages 82-88.

5. breifing, C. (2013, februrary 5). China breifing. Retrieved october 18, 2015, from China breifing: http://www.chinabriefing.com/news/2013/02/05/china-gaap-vs-u-s-gaap-and-ifrs.html

6. C, N. (19998). Towards a general model of the reasons for international differences in financial reporting. ABACUS , Volume 34(2), Pages 162-187.

7. CCAB. (2015). Accountants and Counter-Terrorist Financing . UK: CCAB. 
8. chartered, S. (2012). standard chartered. Retrieved december 23, 2015, from http://reports.standardchartered.com: http://reports.standardchartered.com/annual-report-

2012/supplementaryinformation/financialinformation/bdifferencesbetweenindiangaapifrs.html

9. Choi, F. D. (1991). International Accounting diversity: does it impact market participants. p. working paper no.3590.

10. cpaclass. (2016). U.S. GAAP Codification of Accounting Standards. Retrieved may 9, 2016, from U.S. GAAP Codification of Accounting Standards: http://cpaclass.com/gaap-accounting-standards/gaap-codification-asc-overview.htm

11. D' Arcy, A. (2001). Accounting classification and the international harmonization debate: an empirical investigation. Accounting, Organisations and society, Volume 26, Pages 327-349.

12. Daske, H. H. (2008). Mandatory IFRS reporting around the world. Journal of accounting research , 46(5): $1085-1142$.

13. Deloitte. (2016). UK accounting plus. Retrieved march 6, 2016, from IASplus: http://www.iasplus.com/en-gb/standards/ukgaap

14. F Choi, G. M. (2008). International Accounting. new jersey, united states: Pearson.

15. F Choi, R. 1. (1991). International Accounting Diversity: Does it Affect Market Participants? Financial Analysts Journal , July/August: 73-82.

16. Fatma Jehri, J. C. (2013). Adoption determinants of the international accounting standards IAS/IFRS by developing countries. Journal of economic, finance and administrative science, Pages 56-62.

17. GAAP, U. (2015, january 1). ICAEW. Retrieved april 23, 2016, from ICAEW: http://www.icaew.com/en/library/subjectgateways/accounting-standards/uk-frs

18. Gernon, H. a. (2001). Acounting: An international perspective. Boston: Mcgraw Hills.

19. global, A. (2013, january 1). Acca global. Retrieved februrary 13, 2016, from www.accaglobal.com: http://www.accaglobal.com/ca/en/technical-activities/technical-resources-search/2013/january/uk-accounting-standards.html

20. Global, A. (2015, march 6). ACCA Global. Retrieved may 2, 2016, from ACCA Global: http://www.accaglobal.com/sg/en/technical-activities/technical-resources-search/2015/march/frs102-cashflowstatement.html

21. Guan L, A. L. (2004). An Empirical Evaluation of Environmental Factors Influencing the Adoption of IAS in Asian-Pacific Countries. Journal of Business, Industry and Economics, Volume 4: 61-83.

22. H Daske, L. H. (2008). Mandatory IFRS Reporting Around the World: Early Evidence on the Economic Consequences. 46(5): 1085-1142: Journal of Accounting Research.

23. Hassan R Hassabelnaby, R. W. (2003). The impact of enviornmental factors on accounting development: An Egyptian Study. Critical perspective on accounting, Volume 14, Issue 3, Pages 273-292.

24. Henry B Ramsey, J. F. (1977). Evolution of accounting standards and current developments. Record of society of actuaries , Volume 3, No.4.

25. Hope, J. T. (2006). Empirical evidence on juridications that adopts IFRS. Journal of international accounting research , Volume 5(2), Pages 1-20.

26. ICAI. (2014, september 1). ICAI. Retrieved april 26, 2016, from ICAI: http://www.icai.org/post.html?post_id=8660

27. Kawamura, Y. (2007, july 27). accounting dairy in japan. Retrieved march 2, 2016, from http://accountingdiaryinjapan.blogspot.in: http://accountingdiaryinjapan.blogspot.in/2007_07_01_archive.html

28. Kim M Shima, D. C. (2012). Factors affecting the adoption of IFRS. International journal of business , 17(3), Pages 277298.

29. Lainez A Jose, C. S. (2000). The effect of accounting diversity on international financial analysis: empirical evidence. the international journal of accounting, volume35, issue1,pages 65-83.

30. Mueller, G. (1967). International accounting. new york: Macmillan.

31. Nobes, C. (1983). A judegemental classification of international financial reporting practices. Journal of business, finance and accounting, spring: pages 1-19.

32. Nobes, C. (1998). Towards a General Model of the Reasons for International Differences in Financial Reporting. ABACUS , Volume 34(2): 162-187.

33. PWC. (2015, may 15). inform global. Retrieved april 7, 2016, from inform.pwc: https://inform.pwc.com/inform2/s/IAS_38_Intangible_assets/informContent/0947085303162318

34. Radebaugh L.H., G. S. (2006). International accounting and multinational enterprises. Hoboken, New Jersey: John Wiley \& Sons,Inc.

35. Salter, S. N. (1995). Cultural influence on the development of accounting systems internationally: a test of gray. journal of international business studies, Volume 26(2), Pages 379-397.

36. sawani, a. (2009). The changing accounting enviornment: international accounting standard and US implementation. Journal of finance and accountancy, Pages 1-9.

37. Unegbu, A. O. (2014). Theories of accounting:Evolutions \& developments, Income-determination \& diversities in use. Research journal of financial and accounting, Volume 5, No.15. Pages.

38. WORKMAN, D. (2016, april 7). worldstopexports. Retrieved april 26, 2016, from http://www.worldstopexports.com/indiastop-import-partners/: http://www.worldstopexports.com/indias-top-import-partners/

39. WORKMAN, D. (2016, April 7). WTE. Retrieved may 2, 2016, from WTE: http://www.worldstopexports.com

40. Young, E. \&. (2011). US GAAP vs. IFRS. UK: Ernst \& Young. 